\title{
Association of calf growth traits with production characteristics in dairy cattle
}

\author{
D. L. Van De Stroet, ${ }^{*} \dagger$ J. A. Calderón Díaz, ${ }^{*} \ddagger$ K. J. Stalder, ${ }^{*}$ A. J. Heinrichs, $†$ and C. D. Dechow† ${ }^{1}$ \\ *Department of Animal Science, lowa State University, Ames 50011 \\ †Department of Animal Science, Pennsylvania State University, University Park 16802 \\ ‡Department of Animal Behaviour, Institute of Genetics and Animal Breeding of the Polish Academy of Sciences, ul. Postepu 36A, Jastrzębiec, \\ 05-552 Magdalenka, Poland
}

ABSTRACT

The objective of this study was to understand the associations of calf growth traits with subsequent milk yield and body weight (BW). Data were collected for 281 Holstein heifer calves from 6 different calf trials of varying lengths ( 4 to $8 \mathrm{wk}$ ) conducted at Pennsylvania State University between 2003 and 2010. Calves were classified as high, medium, or low for hip height, starter feed intake, BW, and growth rate. Milk yield and cow BW were recorded during subsequent lactations. In total, there were 169,734 daily milk records and 136,153 cow BW records available. Data were evaluated using mixed model equations. Separate models were used for each calf growth trait initially, followed by models that considered multiple growth measures. Each model included age at calving, treatment within trial, parity, days in milk, lactation, and one of the calf growth traits as well as the interaction between lactation and days in milk as fixed effects. Cow and calendar week by year were fitted as random effects. Heifers from the low hip height classification as calves produced less milk across lactations after accounting for BW differences. Cows from the medium BW classification as calves produced more milk in early lactation than cows from the high BW classification as calves after accounting for differences in height. Calves that grew more quickly, ate more, and weighed more were heavier as first-lactation heifers and as mature cows. Our results suggest that the type of preweaning growth is an important consideration for future milk yield. Calves that were the shortest had the lowest milk production potential and were the least likely to remain in the herd until first lactation.

Key words: calf growth, mature body weight, milk yield, stayability

Received December 9, 2015

Accepted June 11, 2016.

${ }^{1}$ Corresponding author: cdd1@psu.edu

\section{INTRODUCTION}

Strategic selection of replacement heifers could reduce herd input costs as production of replacement heifers accounts for approximately $20 \%$ of the total expenses on dairy farms (Heinrichs, 1993). Moreover, investment in rearing is not fully recovered on a sizeable proportion of replacement animals, as one-third of first-lactation cows do not calve a second time (Wathes et al., 2008). Therefore, it would be helpful to identify indicators early in life that could aid in selecting heifers that are more likely to remain in the herd longer and produce optimal milk yields. Previous studies have suggested that calf measurements could be used to predict productivity later in life, but information in the scientific literature is limited. Swali and Wathes (2006) reported that lighter heifer calves at birth continued to have lesser BW during their first lactation. Lesser birth weights did not affect growth rate, subsequent milk production, or fertility. In contrast, Ghoraishy and Rokouei (2013) reported that low birth weight calves produced less milk later in life. Those authors reported that heifers with high birth weight were younger at first calving but had greater calving to first service, first service to conception and calving intervals, and an increase occurrence of dystocia. Grain intake at weaning, growth rate, and wither height have also been reported to have positive relationships with first-lactation milk yield (Shamay et al., 2005; Moallem et al., 2010; Heinrichs and Heinrichs, 2011; Soberon et al., 2012).

Moderate to strong relationships exist among body and growth measures. Heinrichs et al. (1992) developed quadratic equations to predict BW in Holstein heifers based heart girth, wither height, hip width, and body length. For all the equations, the coefficient of determination was $\geq 0.96$. London et al. (2012) reported a rank correlation of 0.26 between hip height and $\mathrm{BW}$ in 8-mo-old calves at dairy cattle shows in Georgia, whereas Heinrichs and Hargrove (1987) reported a correlation of 0.40 between wither height and $\mathrm{BW}$ for 24-mo-old heifers. Positive relationships between height measurements and ADG, which is a function of feed 
intake, have also been reported (Bar-Peled et al., 1997; Hoffman, 1997; Macdonald et al., 2005; Shamay et al., 2005). Nonetheless, relationships among calf measurements within a population can be difficult to define, as they may vary from calf-to-calf depending upon genetic background (Heinrichs and Hargrove, 1987; Heinrichs et al., 1992).

Understanding the relationships between calf growth characteristics and future productivity would facilitate the development of management strategies to optimize calf growth and enable the selection of replacement heifers based on early-life measurements that are relatively easy to record (Wathes et al., 2008). The objective of our study was to evaluate associations of calf hip height, BW, growth rate, and starter feed intake with subsequent milk yield and BW.

\section{MATERIALS AND METHODS}

\section{Data Set}

Calf Measurements. Data were collected from 281 Holstein heifer calves from 6 different calf trials of varying lengths conducted at Pennsylvania State University from 2003 to 2010. Details on treatment length, time, and calf nutrition were previously described by Heinrichs et al. (2003, 2009), Lesmeister and Heinrichs (2004, 2005), Lesmeister et al. (2004), Kehoe et al. (2007, 2008), and Quezada-Mendoza et al. (2011). Hip height, starter feed intake, growth rate, and BW were measured on each calf for a period ranging from 4 to 8 wk. Two trials had measurements for $6 \mathrm{wk}$ and 4 trials had measurements for $8 \mathrm{wk}$. Data were truncated at 4 wk for 2 of the trials that lasted 8 wk due to incomplete feed intake records. Heifer calf data were ranked into 3 classifications (high, medium, low) of an equal number of calves for hip height, starter feed intake, growth rate, and BW. Our goal was to identify high, medium, and low groups that were due to differences in calf effects and not due to treatment or trial effects. Therefore, hip height, starter feed intake, and BW were evaluated with mixed models that included week of treatment within trial as a fixed effect and calf as a random effect. Calves were then assigned to groups based on the random calf effect. We also wished to evaluate growth rate independent of BW. To do this, we included a random regression of $\mathrm{BW}$ on age nested within calf, with the regression coefficient used to determine high, medium, or low growth rate. This effect was not significant for hip height or starter feed intake, so it was not considered for those traits. Means, standard deviations, and ADG for the high, medium, and low groups for each trait are reported in Table 1.
Milk Yield and Cow BW Measurements. A total of 169,734 daily milk yield records from 226 heifers from the calf trials were collected following twice-daily milkings at the Pennsylvania State University dairy barn. Cow BW was recorded after each milking using an AfiWeigh scale (Afimilk Ltd., Kibbutz Afikim, Israel). In total, 136,153 BW records from 225 cows were included in the data set used for analysis. Heifers without more than 1 milk record were excluded from the milk yield and BW data set. Lactation groups were classified as 1,2 , and $\geq 3$. Days in milk were classified in biweekly groups. Milk yield records greater than 400 DIM were deleted. Total milk yields for 305-d lactations were generated as the sum of daily milk yield from 5 to 305 DIM. For cows with lactation lengths $\geq 100 \mathrm{~d}$ but $<305 \mathrm{~d}$, lactation total milk yield was extrapolated to $305-d$ totals. Age at calving was classified on a monthly basis.

\section{Statistical Analysis}

Each individual cow was considered the experimental unit. Separate models were used to analyze data from the first lactation and data from all lactations. Furthermore, separate models were used to analyze milk yield from all lactations for wk 1 to 10,11 to 20,21 to 30 , and 31 to 40 of lactation and 305-d lactation total yield for each growth trait. Statistical differences were reported when model source of variation was $P \leq 0.05$. When a main effect was a significant source of variation, levels from each main effect were separated using the PDIFF option and a Tukey-Kramer adjustment (SAS ver. 9.3 PROC MIXED, SAS Institute Inc., Cary, NC) was used to account for multiple comparisons between levels. Results for fixed effects are reported as least squares means \pm standard errors. Results for continuous variables are reported as the regression coefficient \pm standard errors.

Milk Yield. The effect of calf growth trait group on milk yield was evaluated using mixed model equations (SAS ver. 9.3 PROC MIXED; SAS Institute Inc., Cary, NC). Models for milk yield for the first lactation included biweekly DIM, one of the calf growth traits, age at calving, and treatment within trial as fixed effects. Cow and calendar week by year were included as random effects. Models for 305-d first lactation total milk yield included age at calving, one of the calf growth traits, and treatment within trial as fixed effects with a random effect of year. The models for milk yield for all lactations included lactation $(1,2, \geq 3)$, biweekly DIM, lactation $\times$ biweekly DIM, one of the calf growth traits, age at calving, and treatment within trial as fixed effects. Cow, cow $\times$ lactation, and calendar week by year were included as random effects. Models for 
Table 1. Weekly means and standard deviations for low, medium, and high classifications of calf growth traits (i.e., hip height, BW, growth rate, and starter feed intake) $)^{1}$

\begin{tabular}{|c|c|c|c|c|c|c|c|c|c|c|c|c|}
\hline \multirow{2}{*}{ Item } & \multicolumn{6}{|c|}{$\mathrm{BW}, \mathrm{kg}$} & \multicolumn{6}{|c|}{ BW for growth rate classifications, $\mathrm{kg}$} \\
\hline & \multicolumn{2}{|c|}{ Low } & \multicolumn{2}{|c|}{ Medium } & \multicolumn{2}{|c|}{ High } & \multicolumn{2}{|c|}{ Low } & \multicolumn{2}{|c|}{ Medium } & \multicolumn{2}{|c|}{ High } \\
\hline \multicolumn{13}{|l|}{ Week } \\
\hline 1 & 37.5 & 3.2 & 43.4 & 3.0 & 48.7 & 3.9 & 42.2 & 5.9 & 41.9 & 4.9 & 45.5 & 5.5 \\
\hline 2 & 38.1 & 2.9 & 44.4 & 3.0 & 50.1 & 4.5 & 43.1 & 6.4 & 42.9 & 5.0 & 46.7 & 5.9 \\
\hline 5 & 48.9 & 5.7 & 55.6 & 5.8 & 59.9 & 6.9 & 50.2 & 6.8 & 53.6 & 5.3 & 60.6 & 6.4 \\
\hline 6 & 54.9 & 6.7 & 61.8 & 7.3 & 64.1 & 9.2 & 53.9 & 7.0 & 59.4 & 5.3 & 67.1 & 7.3 \\
\hline 7 & 62.6 & 7.9 & 67.0 & 8.4 & 71.2 & 10.7 & 59.7 & 8.0 & 66.4 & 4.8 & 75.4 & 7.9 \\
\hline 8 & 69.4 & 9.0 & 74.5 & 9.3 & 77.1 & 11.3 & 65.5 & 8.2 & 73.1 & 5.2 & 82.8 & 8.2 \\
\hline \multirow[t]{3}{*}{$\mathrm{ADG}$} & 0.49 & 0.21 & 0.51 & 0.21 & 0.46 & 0.22 & 0.34 & 0.16 & 0.47 & 0.17 & 0.64 & 0.17 \\
\hline & \multicolumn{6}{|c|}{ Starter feed intake, $\mathrm{kg}$} & \multicolumn{6}{|c|}{ Hip height, cm } \\
\hline & \multicolumn{2}{|c|}{ Low } & \multicolumn{2}{|c|}{ Medium } & \multicolumn{2}{|c|}{ High } & \multicolumn{2}{|c|}{ Low } & \multicolumn{2}{|c|}{ Medium } & \multicolumn{2}{|c|}{ High } \\
\hline \multicolumn{13}{|l|}{ Week } \\
\hline 1 & 0.1 & 0.2 & 0.1 & 0.2 & 0.2 & 0.2 & 77.6 & 2.2 & 81.1 & 2.0 & 83.7 & 1.9 \\
\hline 2 & 0.3 & 0.3 & 0.2 & 0.3 & 0.5 & 0.4 & 78.7 & 2.1 & 82.3 & 1.7 & 85.2 & 2.2 \\
\hline 3 & 0.6 & 0.7 & 0.7 & 0.5 & 1.7 & 1.1 & 79.5 & 2.1 & 83.2 & 1.8 & 86.3 & 2.3 \\
\hline 4 & 1.2 & 1.0 & 1.4 & 0.9 & 3.4 & 1.7 & 80.7 & 2.1 & 84.3 & 1.9 & 87.7 & 2.4 \\
\hline 5 & 2.2 & 1.4 & 3.1 & 1.2 & 5.9 & 2.0 & 82.6 & 2.1 & 85.9 & 2.1 & 89.6 & 2.2 \\
\hline 6 & 4.3 & 2.3 & 5.3 & 2.1 & 8.8 & 3.0 & 84.1 & 2.8 & 87.4 & 2.4 & 90.9 & 2.4 \\
\hline 7 & 8.3 & 3.2 & 12.0 & 2.2 & 14.6 & 2.8 & 86.6 & 2.4 & 89.9 & 1.5 & 93.3 & 2.3 \\
\hline 8 & 14.4 & 4.2 & 16.8 & 2.9 & 20.6 & 2.8 & 87.8 & 2.7 & 91.2 & 1.7 & 94.7 & 2.3 \\
\hline $\mathrm{ADG}$ & 0.41 & 0.17 & 0.37 & 0.19 & 0.64 & 0.17 & 0.45 & 0.20 & 0.46 & 0.21 & 0.54 & 0.21 \\
\hline
\end{tabular}

${ }^{1}$ The data originated from 6 different trials from 2003 to 2010 at Pennsylvania State University. Data were classified in 3 groups for each growth trait using the rank procedure in SAS (SAS ver. 9.3 PROC MIXED; SAS Institute Inc., Cary, NC).

305-d lactation total milk yield included age at calving, one of the calf growth traits, and treatment within trial as fixed effects with random effects of cow and year. Models with multiple calf growth traits were also considered, and hip height and BW were significant when both were included in the same model as fixed effects.

Mature Cow $\boldsymbol{B} \boldsymbol{W}$. Data were analyzed using mixed model equations methods (SAS ver. 9.3 PROC MIXED; SAS Institute Inc.). Models for first-lactation BW included biweekly DIM, one of the calf growth traits, age at calving, and treatment within trial as fixed effects. Cow and calendar week by year were included as random effects. Body weight models for all lactations included lactation group $(1,2, \geq 3)$, biweekly DIM, and their interaction; a single calf growth trait was the fixed effect in the model. Cow, cow $\times$ lactation, and calendar week by year were included as random effects.

Heifer Stayability to First Lactation. An univariate logistic binomial regression model analysis by use of the Wald statistic (PROC GENMOD SAS ver. 9.3; SAS Institute Inc.) was used to investigate the likelihood of calf stayability until the first lactation recorded in relation to the calf growth trait groups.
Results are reported as odds ratios with the associated 95\% confidence intervals. An odds ratio greater than 1 is indicative of increased stayability, whereas an odds ratio less than 1 indicates reduced stayability compared with the reference category.

\section{RESULTS}

When comparing calf growth traits, ADG was highest for the high calf growth rate and starter feed intake classifications $(0.64 \mathrm{~kg} / \mathrm{d}$; Table 1$)$. The correlation between starter intake and growth rate was the highest among traits at $0.77(P<0.001)$. Body weight was not correlated with our measure of growth rate $(\mathrm{r}=0.05 ; P$ $>0.05)$ or starter intake $(\mathrm{r}=0.01 ; P>0.05)$, but was strongly correlated with height $(\mathrm{r}=0.69 ; P<0.001)$. Hip height was moderately correlated with growth rate $(\mathrm{r}=0.35 ; P<0.001)$ and starter feed intake $(\mathrm{r}=0.28$; $P<0.001)$.

\section{First-Lactation Milk Yield}

Heifers that were in the medium hip height classification as calves produced $3.0 \pm 0.9 \mathrm{~kg}$ of milk/d 
more than heifers from the low hip height classification as calves $(P<0.05$; Table 2$)$ throughout their entire lactation. When evaluating specific lactation periods, heifers from the medium calf hip height classification produced $2.5 \pm 0.9 \mathrm{~kg}$ of milk/d more than heifers from the low calf hip height classification during wk 1 to 10 $(P<0.05$; not shown). Throughout wk 11 to 20 , heifers from the medium and high calf hip height classifications produced $2.7 \pm 0.9$ and $3.2 \pm 1.0 \mathrm{~kg}$ of milk/d more than heifers from the low calf hip height category, respectively $(P<0.05$; not shown). A tendency was observed for first-lactation cows from the high starter feed intake classification as calves to produce $2.2 \pm 1.0$ $\mathrm{kg}$ of milk/d more than cows from the low starter feed intake classification as calves $(P=0.06$; not shown). However, we found no significant association of calf $\mathrm{BW}$, growth rate, and starter feed intake classifications with first-lactation milk yield across lactation, within specific lactation periods, or 305-d lactation total milk yields $(P>0.05)$. No significant differences in firstlactation milk yield were observed among hip height classifications for wk 21 to 30 and 31 to 40 of lactation $(P>0.05)$.

Total 305-d first-lactation yields for heifers from the medium and high hip height classifications as calves were $10,171 \pm 286.3$ and $10,112 \pm 280.9 \mathrm{~kg}$ of milk, which were $782.1 \pm 260.3$ and $722.9 \pm 260.3 \mathrm{~kg}$ more milk than heifers from the low calf hip height classification produced, respectively $(P<0.05$; not shown).

\section{Milk Yield for All Lactations}

Throughout their entire lactation, cows from the medium calf hip height classification produced $3.2 \pm$ $1.0 \mathrm{~kg}$ of milk/d than cows from the low calf hip height classification $(P<0.05$; Table 2$)$. Cows from the high calf hip height classification also tended to produce $2.3 \pm 1.0 \mathrm{~kg}$ of milk/d more than cows from the low calf hip height classification. Differences were also significant when both BW and hip height classifications were included in the same model (Table 3). Across the entire lactation, cows from the medium and high hip height classifications as calves produced $3.8 \pm 1.1$ and $3.5 \pm 1.2 \mathrm{~kg}$ of milk/d more than cows from the low hip height classification, respectively $(P<0.05)$.

When evaluating milk yield for wk 1 through 10, cows from the medium hip height classification as calves produced $3.1 \pm 0.9 \mathrm{~kg}$ of milk/d more than cows from the low calf hip height classification $(P<0.05$; Table 3). Cows from the medium BW classification as calves produced $2.2 \pm 0.9 \mathrm{~kg}$ of milk/d more than cows from the high BW calf classification $(P<0.05$; Table 3). Cows from the high hip height classification as calves also tended to produce $2.1 \pm 1.0 \mathrm{~kg}$ of milk/d
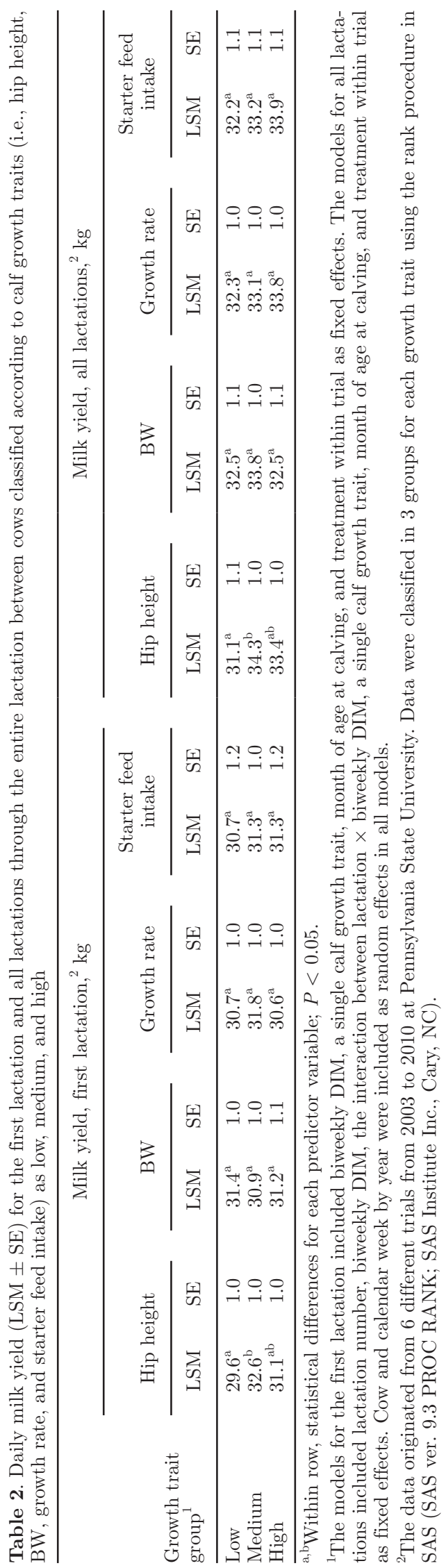
than cows from the low calf hip height classification $(P$ $=0.09$; Table 3). When BW was not included in the model, cows from the medium calf hip height classification produced $2.6 \pm 0.9 \mathrm{~kg}$ of milk/d more than cows from the low calf hip height classification $(P<0.05$; not shown). Cows from the high calf starter feed intake classification also tended to produce $1.7 \pm 0.8 \mathrm{~kg}$ of milk/d more than cows from the low starter feed intake classification as calves $(P=0.09$; not shown).

For wk 11 through 20, cows from the medium and high calf hip height classification produced $3.4 \pm 1.1$ and $3.4 \pm 1.2 \mathrm{~kg}$ of milk/d more than cows originating from the low calf hip height classification, respectively $(P<0.05$; Table 3$)$. This relationship was also significant when BW was not included in the model as cows classified in the medium and high hip height classifications as calves produced $3.0 \pm 1.0$ and $2.4 \pm 1.0 \mathrm{~kg}$ of milk/d more than cows from the low hip height classification as calves, respectively ( $P<0.05$; not shown). No statistical difference in milk yield was detected for calf starter feed intake or growth rate classifications. We observed no association between calf growth trait classifications and milk yield for wk 21 through 30 and wk 31 through 40 of lactation $(P>0.05)$.

Total 305-d lactation yields for cows from the medium calf hip height classification were 11,802 $\pm 212.2 \mathrm{~kg}$ of milk, which was $699.44 \pm 274.5 \mathrm{~kg}$ more milk than cows from the low calf hip height classification produced $(P$ $<0.05$; not shown). When both BW and hip height classifications were included in the same model, total 305-d lactation yields for cows from the medium calf hip height classification were $11,785 \pm 211.7 \mathrm{~kg}$ of milk, which was $822.6 \pm 295.0 \mathrm{~kg}$ more milk than produced by cows from the low calf hip height classification $(P$ $<0.05$; not shown). Cows from the high calf hip height classification also tended to produce $715.6 \pm 324.7 \mathrm{~kg}$ more total milk than cows from the low hip height classification ( $P=0.07$; not shown). Cows from the medium calf BW classification tended to produce 655.9 $\pm 282.5 \mathrm{~kg}$ more total milk than cows from the high calf BW classification ( $P=0.05$; not shown).

\section{First-Lactation BW}

Heifers from the high calf starter feed intake classification were $27.3 \pm 8.3 \mathrm{~kg}$ heavier than heifers from the low calf starter feed intake classification $(P<0.05$; Table 4). Heifers from the high growth rate classification as calves weighed $27.1 \pm 8.4 \mathrm{~kg}$ more than heifers from the low calf growth rate classification $(P<0.05$; Table 4). Heifers from the medium calf growth rate classification also tended to weigh $18.1 \pm 8.7 \mathrm{~kg}$ more than heifers from the low growth rate classification as calves $(P=0.09$; Table 4$)$. Heifers from the high calf BW classification weighed $24.6 \pm 8.6 \mathrm{~kg}$ more than heifers from the low BW classification as calves $(P<$ 0.05; Table 4). Heifers from the high hip height classification as calves also weighed $23.9 \pm 8.6 \mathrm{~kg}$ more than heifers from the low calf hip height classification $(P<0.05 ;$ Table 4$)$.

\section{Cow BW for All Lactations}

Cows from the high calf growth rate classification were $29.8 \pm 8.3 \mathrm{~kg}$ heavier as cows than cows from the low calf growth rate classification $(P<0.05$; Table 4$)$. Cows from the high calf starter feed intake classification were $26.8 \pm 8.4 \mathrm{~kg}$ heavier than cows from the low calf starter feed intake classification $(P<0.05$; Table $4)$. Cows from the medium and high calf BW classifications weighed $22.4 \pm 8.7$ and $21.1 \pm 8.5 \mathrm{~kg}$ more than cows from the low BW classification as calves, respectively $(P<0.05$; Table 4$)$. A tendency was also observed for cows from the high calf hip height classifi-

Table 3. Daily milk yield for all lactations $(\mathrm{LSM} \pm \mathrm{SE})$ in kilograms every $10 \mathrm{wk}$ and for the entire lactation between cows classified according to hip height or BW as low, medium, and high

\begin{tabular}{|c|c|c|c|c|c|c|c|c|c|c|c|c|}
\hline \multirow{2}{*}{$\begin{array}{l}\text { Weeks of } \\
\text { lactation }^{1}\end{array}$} & \multicolumn{6}{|c|}{ Hip height ${ }^{2}$} & \multicolumn{6}{|c|}{$\mathrm{BW}^{2}$} \\
\hline & LSM & $\mathrm{SE}$ & LSM & $\mathrm{SE}$ & LSM & SE & LSM & $\mathrm{SE}$ & LSM & $\mathrm{SE}$ & LSM & $\mathrm{SE}$ \\
\hline Entire lactation & $30.4^{\mathrm{a}}$ & 1.1 & $34.2^{\mathrm{b}}$ & 1.0 & $33.9^{\mathrm{b}}$ & 1.0 & $33.6^{\mathrm{a}}$ & 1.1 & $33.5^{\mathrm{a}}$ & 1.0 & $31.4^{\mathrm{a}}$ & 1.1 \\
\hline $1-10$ & $36.0^{\mathrm{a}}$ & 1.0 & $39.1^{\mathrm{b}}$ & 1.0 & $38.1^{\mathrm{ab}}$ & 1.0 & $38.3^{\mathrm{ab}}$ & 1.0 & $38.5^{\mathrm{a}}$ & 0.9 & $36.3^{\mathrm{b}}$ & 1.0 \\
\hline $11-20$ & $38.8^{\mathrm{a}}$ & 1.2 & $42.2^{\mathrm{b}}$ & 1.1 & $42.2^{\mathrm{b}}$ & 1.1 & $41.7^{\mathrm{a}}$ & 1.2 & $41.8^{\mathrm{a}}$ & 1.0 & $39.7^{\mathrm{a}}$ & 1.1 \\
\hline
\end{tabular}


cation to weigh $19.1 \pm 8.6 \mathrm{~kg}$ more than cows from the low calf hip height classification $(P=0.07$; Table 4$)$.

\section{Heifer Stayability to First Lactation}

Fifty-seven heifer calves did not remain in the herd until first lactation. Reasons for removal included reproductive failure, death, injury or illness, and no reason given for 36, 10, 6, and 4 heifers, respectively. One heifer was culled for research purposes and was removed from the stayability analysis. Calf BW and starter feed intake were not significantly associated with remaining in the herd until first lactation $(P>$ 0.05). Calves from the medium hip height classification were the most likely to survive to first lactation. The odds of survival to first lactation versus being culled were $3.8: 1,10.7: 1$, and 3.4:1 for low, medium, and high hip height, respectively. Thus, the survival odds ratio was 2.8:1 for the medium hip height calves to low hip height calves (95\% CI: 1.1 to $7.1 ; P<0.05$; not shown). Odds for calves from the high hip height classification were 0.3 (95\% CI: 0.1 to $0.8 ; P<0.05$; not shown) when compared with calves from the medium hip height classification. Calves from the high growth rate classification had odds of survival to first lactation of 3.4:1 (95\% CI: 1.2 to 9.1) and 2.4:1 (95\% CI: 1.0 to 5.6) when compared with calves from the low and medium growth rate classifications, respectively $(P<0.05$; not shown).

\section{DISCUSSION}

Given the nature of our data set, growth rate classifications were defined somewhat differently than in many studies. The individual calf trials varied in length which would have limited consideration of the calf re- cords to the shortest recording period ( $4 \mathrm{wk}$ ) if we were to compare growth characteristics directly across studies. More importantly, the calf records were recorded over several years and under different experimental conditions. Comparing calf growth directly would have identified groups based on time and trial characteristics rather than differences due to calf effects. For these reasons, calves were classified into high, medium, and low groups after adjusting for trial.

\section{Milk Yield}

Results from the present study suggest that calves with low hip height had lower milk yield than taller calves. This was particularly true during the peak of lactation for both the first lactation and subsequent lactations. Whereas, to our knowledge, no other study has investigated the association between preweaning calf hip height and subsequent milk yield, studies have reported positive associations between milk yield and height in older females. Sieber et al. (1988) and Markusfeld and Ezra (1993) obtained low but positive correlations between wither height and milk yield (0.21 to 0.22 ) for lactating dairy cows, whereas Shanks and Spahr (1982) reported a phenotypic correlation between hip height and daily milk yield of 0.19. Brotherstone (1994) also found positive genetic and phenotypic correlations between stature and milk, fat, and protein yields. Furthermore, Heinrichs and Hargrove (1987) observed that the correlation between wither height and first-lactation milk yield (0.41) was greater than that of BW (0.34) on heifers measured between 1 and 24 mo of age and first-lactation milk yield.

During wk 1 to 10 of lactation over all lactations, cows which were heavy and short as calves produced less milk than their contemporaries. One explanation

Table 4. Body weight (LSM \pm SE) in kilograms for cows classified according to calf growth traits (i.e., hip height, BW, growth rate, and starter feed intake) as low, medium, and high

\begin{tabular}{|c|c|c|c|c|c|c|c|c|c|}
\hline Lactation & $\begin{array}{l}\text { Growth trait } \\
\text { group }\end{array}$ & \multicolumn{2}{|c|}{ Hip height ${ }^{1}$} & \multicolumn{2}{|c|}{$\mathrm{BW}^{1}$} & \multicolumn{2}{|c|}{ Growth rate $^{1}$} & \multicolumn{2}{|c|}{ Starter feed intake } \\
\hline \multirow[t]{2}{*}{$\overline{\mathrm{One}^{2}}$} & Low & $596.4^{\mathrm{a}}$ & 9.8 & $598.4^{\mathrm{a}}$ & 9.7 & $597.1^{\mathrm{a}}$ & 9.5 & $595.1^{\mathrm{a}}$ & 11.3 \\
\hline & High & $620.3^{\mathrm{b}}$ & 9.3 & $623.0^{\mathrm{b}}$ & 9.9 & $624.2^{\mathrm{b}}$ & 9.8 & $622.4^{\mathrm{b}}$ & 11.6 \\
\hline \multirow[t]{2}{*}{$\mathrm{All}^{3}$} & Low & $659.1^{\mathrm{a}}$ & 7.4 & $653.8^{\mathrm{a}}$ & 7.2 & $652.8^{\mathrm{a}}$ & 7.1 & $653.8^{\mathrm{a}}$ & 7.7 \\
\hline & Medium & $668.5^{\mathrm{a}}$ & 6.8 & $676.2^{\mathrm{b}}$ & 7.0 & $669.8^{\mathrm{ab}}$ & 6.8 & $672.1^{\mathrm{ab}}$ & 7.9 \\
\hline
\end{tabular}

\footnotetext{
${ }_{\mathrm{a}, \mathrm{b}}$ Within column and lactation statistical differences for each predictor variable; $P<0.05$.

${ }^{1}$ The data originated from 6 different trials from 2003 to 2010 at Pennsylvania State University. Data were classified in 3 groups for each growth trait using the rank procedure in SAS (SAS ver. 9.3 PROC RANK; SAS Institute Inc., Cary, NC).

${ }^{2}$ Models included biweekly DIM, one of the calf growth traits, age at calving, and treatment within trial as fixed effects. Cow and calendar week by year were included as random effects in all models.

${ }^{3}$ Models included lactation number, biweekly DIM, the interaction between lactation $\times$ biweekly DIM, a single calf growth trait, and treatment within trial as fixed effects. Cow, cow $\times$ lactation, and calendar week by year were included as random effects in all models.
} 
for the observation of lowered milk yield in high BW calves could be differences in body condition. Whereas body condition was not measured in our study, height was accounted for in the model. This suggests that any significant observations due to BW were a function of increased weight due to muscle or fat and not height. Some studies have suggested adverse effects of increased fat deposition in the udder on subsequent milk yield (Sejrsen et al., 1982; Owens et al., 1993) and that the composition of the mammary fat pad can be affected before weaning (Daniels et al., 2009). Other research has also demonstrated that calves with greater BW have more adipose tissue deposited on their udders (Sejrsen et al., 1982; Capuco et al., 1995). An unfavorable genetic correlation between lactating cow BW and milk yield was previously demonstrated in the Penn State experimental herd (Toshniwal et al., 2008); however, that was due to a strong genetic correlation between BW and BCS (0.60) and the relationship between milk yield and BW was favorable after accounting for that relationship. That result is supportive of the results observed in the current study. Calves that are taller produced more milk, but calves with high BW after accounting for differences in height are presumed to have higher body condition and produced less milk. This has similarities to a previous meta-analysis investigating prepubertal ADG and first lactation milk production where medium growth rates had significant improvements in milk production over low and high rates of growth (Zanton and Heinrichs, 2005).

No differences in milk yield were observed between calf growth rate and starter feed intake groups; however, we noted a tendency observed for first-lactation cows from the high-calf starter feed intake group to produce more milk than those from the low group during the peak of lactation, which corresponds to observations from commercial herds that higher weaning weight DMI is associated with higher yield (Heinrichs and Heinrichs, 2011). Recent studies also report higher milk yields associated with increased growth rates (ADG of 0.66 to 0.82; Moallem et al., 2010; Soberon et al., 2012). We did not find a significant relationship between milk yield and calf growth rate classifications, which could be attributed to the comparatively lower ADG reported in our study (Table 1) or it may reflect the influence of fat deposition on growth rate rather than frame growth.

\section{Cow BW}

High calf BW, starter feed intake, and growth rate classifications were associated with higher lactating cow BW for all lactations. Increased starter feed intake in calves and, subsequently, increased growth rate re- sulted in increased BW after first calving. Calves that grew faster weighed more after first calving than calves that grew slower before weaning. Whereas few studies have shown the effect of calf growth traits on BW after calving, higher growth rates due to genetic differences have resulted in increased BW (Hohenboken et al., 1995; Sejrsen et al., 2000). Bar-Peled et al. (1997) also indicated that calves which grew faster had increased BW both as calves and at breeding, which supports our observations that high growth rate and BW classification calves had increased cow BW. The observation that first-lactation BW was greater for high than low calf hip height classification heifers may be due to moderate genetic and phenotypic correlations between hip height and BW (0.50 and 0.46, respectively; Koenen and Groen, 1998). It is important to note that the ratio of BW to hip height increases with age, which could make cow BW differences between calf hip height classifications more difficult to discern (Kertz et al., 1998). The faster growth rates and BW observed in the calves from the high growth rate and BW classifications, respectively, could be retained throughout life and may result in increased BW after first calving and through subsequent lactations.

\section{Heifer Stayability to First Lactation}

Calf hip height and growth rate classifications were related to the likelihood of remaining in the herd until first parity. Heifers with the highest and lowest hip heights were less likely to remain in the herd to first lactation than heifers with medium hip heights. Only 6 heifers from the medium calf hip height classification were culled for reproductive reasons, whereas 14 and 16 heifers from the low and high calf hip height classifications, respectively, were culled for reproductive reasons. Henderson et al. (2011) reported a negative genetic correlation between body measurements, including stature, and remaining in the herd until exit. This could be attributed to increased dystocia at birth and subsequent reproductive problems, which have been shown to be greater in higher-birth weight calves (Sieber et al., 1989; Henderson et al., 2011; Ghoraishy and Rokouei, 2013). The increased likelihood for calves from the medium hip height group to remain in the herd until first calving as opposed to calves from the low hip height group is not clear. Several studies in other species have indicated that small prenatal body size negatively affects future reproduction parameters (Rhind, 2004; Zieba et al., 2005); however, conflicting results have been reported in cattle (Bar-Peled et al., 1997; Swali and Wathes, 2006).

High growth rate classification calves were more likely to remain in the herd until first lactation rather 
than die or be culled. Only 2 high growth rate classification calves died or were culled due to illness or injury whereas 8 and 11 calves from the low and medium calf growth rate classifications, respectively, died or were removed because of injury or illness. The increased likelihood for high growth rate classification calves to remain in the herd until first lactation may be attributed to the fact that calves which are ill grow slower (Van Amburgh, 2008) and is consistent with previously reported literature. Henderson et al. (2011) observed that calves with greater weaning weights were less likely to die or be culled before exit. Those authors speculated that this result was due to increased growth rates and decreased disease occurrence.

\section{CONCLUSIONS}

This study concurs with others that preweaning growth has associations with milk yield in later life. Differences in milk yield were most apparent during early and peak lactation. In particular, calves that were the shortest had the lowest milk production potential and were the most likely to be removed from the herd before first lactation. Higher calf growth rates in this study were not significantly associated with future milk yield but were associated with higher BW in lactating cows and higher odds of survival to first lactation.

\section{REFERENCES}

Bar-Peled, U., B. Robinzon, E. Maltz, H. Tagari, Y. Folman, I. Bruckental, H. Voet, H. Gacitua, and A. R. Lehrer. 1997. Increased weight gain and effects on production parameters of Holstein heifer calves that were allowed to suckle from birth to six weeks of age. J. Dairy Sci. 80:2523-2528.

Brotherstone, S. 1994. Genetic and phenotypic correlations between linear type traits and production traits in Holstein-Friesian dairy cattle. Anim. Prod. 59:183-187.

Capuco, A. V., J. J. Smith, D. R. Waldo, and C. E. Rexroad. 1995 Influence of prepubertal dietary regimen on mammary growth of Holstein heifers. J. Dairy Sci. 78:2709-2725. http://dx.doi. org/10.3168/jds.S0022-0302(95)76902-8.

Daniels, K. M., A. V. Capuco, M. L. McGilliard, R. E. James, and R. M. Akers. 2009. Effects of milk replacer formulation on measures of mammary growth and composition in Holstein heifers. J. Dairy Sci. 92:5937-5950. http://dx.doi.org/10.3168/jds.2008-1959.

Ghoraishy, S. H., and M. Rokouei. 2013. Impact of birth weight of Iranian Holstein calves on their future milk production and reproductive traits. J. Livest. Sci. Technol. 1:41-46.

Heinrichs, A. J. 1993. Raising dairy replacements to meet the needs of the 21st century. J. Dairy Sci. 76:3179-3187. http://dx.doi. org/10.3168/jds.S0022-0302(93)77656-0.

Heinrichs, A. J., and G. L. Hargrove. 1987. Standards of weight and height for Holstein heifers. J. Dairy Sci. 70:653-660. http://dx.doi. org/10.3168/jds.S0022-0302(87)80055-3.

Heinrichs, A. J., and B. S. Heinrichs. 2011. A prospective study of calf factors affecting first-lactation and lifetime milk production and age of cows when removed from the herd. J. Dairy Sci. 94:336-341. http://dx.doi.org/10.3168/jds.2010-3170.

Heinrichs, A. J., C. M. Jones, J. A. Elizondo-Salazar, and S. J. Terrill. 2009. Effects of a prebiotic supplement on health of neonatal dairy calves. Livest. Sci. 125:149-154. http://dx.doi.org/10.1016/j. livsci.2009.04.003.

Heinrichs, A. J., C. M. Jones, and B. S. Heinrichs. 2003. Effects of mannan oligosaccharide or antibiotics in neonatal diets on health and growth of dairy calves. J. Dairy Sci. 86:4064-4069. http:// dx.doi.org/10.3168/jds.S0022-0302(03)74018-1.

Heinrichs, A. J., G. W. Rogers, and J. B. Cooper. 1992. Predicting body weight and wither height in Holstein heifers using body measurements. J. Dairy Sci. 75:3576-3581. http://dx.doi.org/10.3168/ jds.S0022-0302(92)78134-X.

Henderson, L., F. Miglior, A. Sewalem, D. Kelton, A. Robinson, and K. E. Leslie. 2011. Estimation of genetic parameters for measures of calf survival in a population of Holstein heifer calves from a heifer-raising facility in New York State. J. Dairy Sci. 94:461-470. http://dx.doi.org/10.3168/jds.2010-3243.

Hoffman, P. C. 1997. Optimum body size of Holstein replacement heifers. J. Anim. Sci. 75:836-845.

Hohenboken, W. D., J. Foldager, J. Jensen, P. Madsen, and B. B. Andersen. 1995. Breed and nutritional effects and interactions on energy intake, production and efficiency of nutrient utilization in young bulls, heifers and lactating cow. Acta Agric. Scand. A Anim. Sci. 45:92-98. http://dx.doi.org/10.1080/09064709509415836.

Kehoe, S. I., C. D. Dechow, and A. J. Heinrichs. 2007. Effects of weaning age and milk feeding frequency on dairy calf growth, health and rumen parameters. Livest. Sci. 110:267-272. http://dx.doi. org/10.1016/j.livsci.2006.11.007.

Kehoe, S. I., A. J. Heinrichs, C. R. Baumrucker, and D. L. Greger 2008. Effects of nucleotide supplementation in milk replacer on small intestinal absorptive capacity in dairy calves. J. Dairy Sci. 91:2759-2770. http://dx.doi.org/10.3168/jds.2007-0751.

Kertz, A. F., B. A. Barton, and L. F. Reutzel. 1998. Relative efficiencies of wither height and body weight increase from birth until first calving in Holstein cattle. J. Dairy Sci. 81:1479-1482. http:// dx.doi.org/10.3168/jds.S0022-0302(98)75712-1.

Koenen, E. P., and A. F. Groen. 1998. Genetic evaluation of body weight of lactating Holstein heifers using body measurements and conformation traits. J. Dairy Sci. 81:1709-1713. http://dx.doi. org/10.3168/jds.S0022-0302(98)75738-8.

Lesmeister, K. E., and A. J. Heinrichs. 2004. Effects of corn processing on growth characteristics, rumen development, and rumen parameters in neonatal dairy calves. J. Dairy Sci. 87:3439-3450. http:// dx.doi.org/10.3168/jds.S0022-0302(04)73479-7.

Lesmeister, K. E., and A. J. Heinrichs. 2005. Effects of adding extra molasses to a texturized calf starter on rumen development, growth characteristics, and blood parameters in neonatal dairy calves. J. Dairy Sci. 88:411-418. http://dx.doi.org/10.3168/jds. S0022-0302(05)72702-8.

Lesmeister, K. E., A. J. Heinrichs, and M. T. Gabler. 2004. Effects of supplemental yeast (Saccharomyces cerevisiae) culture on rumen development, growth characteristics, and blood parameters in neonatal dairy calves. J. Dairy Sci. 87:1832-1839. http://dx.doi. org/10.3168/jds.S0022-0302(04)73340-8.

London, M. L., J. K. Bernard, M. A. Froetschel, J. K. Bertrand, and W. M. Graves. 2012. The relationship between weight, age, and average daily gain to show performance of Georgia 4-H and Future Farmers of America (FFA) commercial dairy heifers. J. Dairy Sci. 95:986-996. http://dx.doi.org/10.3168/jds.2011-4599.

Macdonald, K. A., J. W. Penno, A. M. Bryant, and J. R. Roche. 2005 Effect of feeding level pre- and post-puberty and body weight at first calving on growth, milk production, and fertility in grazing dairy cows. J. Dairy Sci. 88:3363-3375. http://dx.doi.org/10.3168/ jds.S0022-0302(05)73020-4.

Markusfeld, O., and E. Ezra. 1993. Body measurements, metritis, and postpartum performance of first lactation cows. J. Dairy Sci. 76:3771-3777. http://dx.doi.org/10.3168/jds.S00220302(93)77720-6.

Moallem, U., D. Werner, H. Lehrer, M. Zachut, L. Livshitz, S. Yakoby, and A. Shamay. 2010. Long-term effects of ad libitum whole milk prior to weaning and prepubertal protein supplementation on skeletal growth rate and first-lactation milk production. J. Dairy Sci. 93:2639-2650. http://dx.doi.org/10.3168/jds.2009-3007. 
Owens, F. N., P. Dubeski, and C. F. Hanson. 1993. Factors that alter the growth and development of ruminants. J. Anim. Sci. 71:3138 3150 .

Quezada-Mendoza, V. C., A. J. Heinrichs, and C. M. Jones. 2011. The effects of a prebiotic supplement (Prebio Support) on fecal and salivary IgA in neonatal dairy calves. Livest. Sci. 142:222-228. http://dx.doi.org/10.1016/j.livsci.2011.07.015.

Rhind, S. M. 2004. Effects of maternal nutrition on fetal and neonatal reproductive development and function. Anim. Reprod. Sci. 8283:169-181. http://dx.doi.org/10.1016/j.anireprosci.2004.04.003.

Sejrsen, K., J. T. Huber, H. A. Tucker, and R. M. Akers. 1982. Influence of nutrition of mammary development in pre- and postpubertal heifers. J. Dairy Sci. 65:793-800. http://dx.doi.org/10.3168/ jds.S0022-0302(82)82268-6.

Sejrsen, K., S. Purup, M. Vestergaard, and J. Foldager. 2000. High body weight gain and reduced bovine mammary growth: Physiological basis and implications for milk yield potential. Domest. Anim. Endocrinol. 19:93-104. http://dx.doi.org/10.1016/S07397240(00)00070-9.

Shamay, A., D. Werner, U. Moallem, H. Barash, and I. Bruckental. 2005. Effect of nursing management and skeletal size at weaning on puberty, skeletal growth rate, and milk production during first lactation of dairy heifers. J. Dairy Sci. 88:1460-1469.

Shanks, R. D., and S. L. Spahr. 1982. Relationships among udder depth, hip height, hip width, and daily milk production in Holstein cows. J. Dairy Sci. 65:1771-1775. http://dx.doi.org/10.3168/jds. S0022-0302(82)82415-6.

Sieber, M., A. E. Freeman, and D. H. Kelley. 1988. Relationships between body measurements, body weight, and productivity in Holstein dairy cows. J. Dairy Sci. 71:3437-3445. http://dx.doi. org/10.3168/jds.S0022-0302(88)79949-X.

Sieber, M., A. E. Freeman, and D. H. Kelley. 1989. Effects of body measurements and weight on calf size and calving difficulty of
Holsteins. J. Dairy Sci. 72:2402-2410. http://dx.doi.org/10.3168/ jds.S0022-0302(89)79373-5.

Soberon, F., E. Raffrenato, R. W. Everett, and M. E. Van Amburgh. 2012. Preweaning milk replacer intake and effects on long-term productivity of dairy calves. J. Dairy Sci. 95:783-793. http:// dx.doi.org/10.3168/jds.2011-4391.

Swali, A., and D. C. Wathes. 2006. Influence of the dam and sire on size at birth and subsequent growth, milk production and fertility in dairy heifers. Theriogenology 66:1173-1184. http://dx.doi. org/10.1016/j.theriogenology.2006.03.028.

Toshniwal, J. K., C. D. Dechow, B. G. Cassell, J. A. D. R. N. Appuhamy, and G. A. Varga. 2008. Heritability of electronically recorded daily body weight and correlations with yield, dry matter intake, and body condition score. J. Dairy Sci. 91:3201-3210. http://dx.doi.org/10.3168/jds.2007-0627.

Van Amburgh, M. E. 2008. Early life management and long-term productivity in dairy calves. Pages 1-8 in Dairy Health Management Certificate Program Proceedings. Ontario Veterinary College, Guelph, ON, Canada.

Wathes, D. C., J. S. Brickell, N. E. Bourne, A. Swali, and Z. Cheng. 2008. Factors influencing heifer survival and fertility on commercial dairy farms. Animal 2:1135-1143. http://dx.doi.org/10.1017/ S1751731108002322.

Zanton, G. I., and A. J. Heinrichs. 2005. Meta-analysis to assess effect of prepubertal average daily gain of Holstein heifers on firstlactation production. J. Dairy Sci. 88:3860-3867. http://dx.doi. org/10.3168/jds.S0022-0302(05)73071-X.

Zieba, D. A., M. Amstalden, and G. L. Williams. 2005. Regulatory roles of leptin in reproduction and metabolism: A comparative review. Domest. Anim. Endocrinol. 29:166-185. http://dx.doi. org/10.1016/j.domaniend.2005.02.019. 